\title{
DESIGN, FABRICATION AND DYNAMIC ANALYSIS OF TWO WHEELER REAR SHOCK ABSORBER EQUIPPED WITH V-MEMBER
}

\author{
G. Sakthi balan, A. Shyaam shylash, K. Swarup, G. Vignesh kannan, R. Sivasurya. \\ Department of Mechanical Engineering, \\ K.Ramakrishnan College of Engineering, Samayapuram, Trichy
}

\begin{abstract}
Today's world the road way transportation is very important mode of navigation. In two wheeled vehicles the loads get varied according to their purpose. Many of bike manufactures are considering that the load distributed from the driver sitting point to rear wheel so shock absorber is mounted at a particular inclined angle for the load distribution. This shock absorber action will be more applicable for when the driver alone in the job but not quite suitable when any passenger are loaded in commercial two wheeler and for carrying the cargo. Due to this inclination, efficiency of the shock absorber is reduced and bending of damper, springs and locking of springs are take place. In order to overcome these problems v-frame through which shock absorber can be adjusted for different loading actions is tested for the better distribution of load in all aspects of load condition. According to the impact from the seat to the rear wheel of the two wheelers, the shock absorber is adjusted in the predetermined position in the sleeve provided in the $v$ member. By mounting the shock absorber in the v-bar, it is possible to distribute the load in all aspect condition which will prevent the bending of damper and springs and improve the efficiency of the shock absorber.
\end{abstract}

Keywords: suspension; v-member; shock absorber; two wheelers; damper.

\section{INTRODUCTION}

Suspension is the vital part in an vehicle to distribute the load evenly, while distributing the load it tend to some bouncing of spring .Bouncing of spring should come suddenly to rest or to lower bounce, in order to attain that condition .The spring material are changed to arrest the over bouncing action (2012) [1] .To increase the comfort ability of the vehicle, the spring thickness is varied and evaluated in various load condition for better suspension effect (2013) [2]. Stress is developed in the suspension spring due to the cyclic load of the suspension by dynamic action and steps taken to reduce the stress induced in the spring and calculating the life time of spring using MSC software (2013) [3]. Spring are manufactured by three different material similarly subjected to various load condition and the fracture created in the spring are examined through the scanning electron microscope $(2013)[3,4]$. Reduce the spring weight in the suspension by manufacturing them in a composite material and scrutinized through the ANSYS software (2012) [5]. Spring composition are varied, tested in very high frequency level and inspect the fracture occur in the spring through scanning electron microscope (2013, 2013, 2011) $[3,4,6]$.suspension effect is get improved through combination of mechanical and electronic devices in the suspension system, it consist of ball screw inerter and permanent magnet electric machinery to measure the impedance of suspension and to control them through mechatronic system (2010) [7]. PID controller is used to isolate both the vehicle weight, road shocks from the suspension and result in overshoot of sprung mass (2008) [8]. By varying the camber angle of the two suspension in different angle which make the car to reduce the maximum frictional forces (2005) [9]

In this paper, a method is revealed to improve the suspension effect and to prevent the locking of spring in two wheeler rear shock absorber of heavy duty vehicle, by equipping the suspension with the $\mathrm{V}$-member at various angle of position to distribute the load evenly through the V-member.

\section{MATERIALS AND METHODS}

Material selected for the V-Member is AISI 1018 mild steel and the chemical composition of the mild steel 1018 is tabulate below

Table 1 Chemical composition of Mild steel 1018

\begin{tabular}{|c|c|}
\hline Elements & Percentage of Elements \\
\hline Carbon & $0.14-0.20 \%$ \\
\hline Iron & $98.81-99.26 \%$ \\
\hline Manganese & $0.60-0.90 \%$ \\
\hline Phosphorus & $0.040 \%$ \\
\hline Sulphur & $0.05 \%$ \\
\hline
\end{tabular}

\section{A. EXISTING MODEL SETUP}

In some heavy duty bikes like TVS MAX 4R, they use totally four shock absorbers to withstand high load application. This same load caring capacity can be achieved in heavy duty bikes by equipping the single shock absorber in the 
V-Member at the each side of the bike. It will increase the springing action, spring locking condition at heavy load application, and damping performance of the dampers and it can able to increase the passenger comfort to an next level. It also reduce cost for buying extra shock absorbers and weight reduction also be achieved.

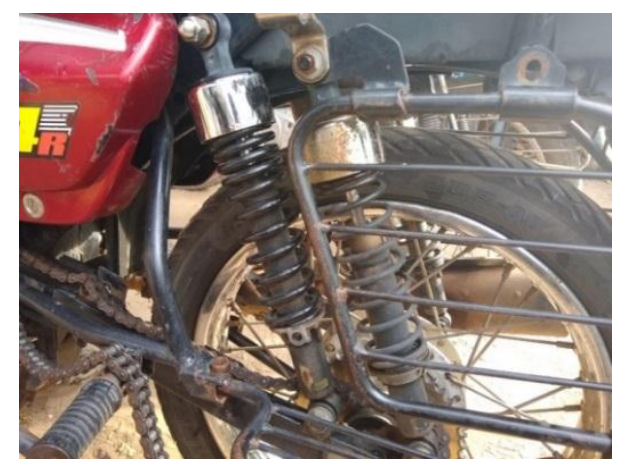

Fig. 1. Existing rear suspension system in TVS Max $100 \mathrm{R}$ model

\section{B. NEW MODEL SETUP EQUIPPED WITH V- MEMBER}

$\mathrm{V}$-member is the supporting member, were the shock absorbers are mounted on it. It is in V-shape, so it is called as $\mathrm{v}$-member and it is also like wishbone shape when it is viewed from any side. V-member consist of two main supporting members and two mounting plate forms, one top member which is mounted to the passenger seat surface to distribute the load from the passenger compartment, one bottom member which is fixed at the rear wheel position, to transmit the load to the rear wheel and two v-member supporting with drilled vmember which use to mount the shock absorber and also to adjust the shock according to their determined position at the drilled slots. These four members are connected with rubber brush to clamp each other, so that it can adjust according to the varying load. Sleeve is cut on the lateral surface of the vbar so According to the impact from the seat to the rear wheel of the two wheelers, the shock absorber is adjusted in the predetermined position in the sleeve provided in the $\mathrm{v}$-bar.

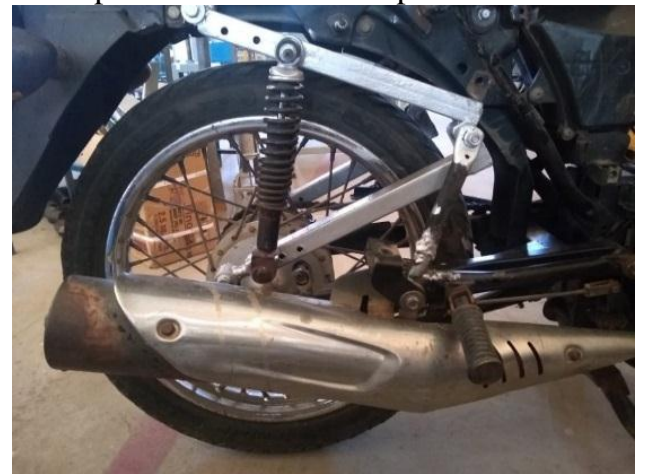

Fig. 2. New Model setup equipped with V-Member

\section{RESULTS AND DISCUSSION}

\section{After modifying the rear suspension system}

In this testing, dynamic analysis was carried out through the ANSYS software and also did real time load testing by the following methods.

- Without V-Member in the rear suspension system (Existing system)

- With rear suspension equipped with V-MEMBER and suspension inclined at $45^{\circ}$ angle

- With rear suspension equipped with V-MEMBER and suspension inclined at $55^{\circ}$ angle

- With rear suspension equipped with V-MEMBER and suspension inclined at $90^{\circ}$ angle.

Table 2 Spring test for determining the Loading capacity of the rear suspension springs without $\mathrm{V}$-member

\begin{tabular}{|c|c|c|c|c|c|}
\hline Sl.No & $\begin{array}{c}\text { Driver } \\
\text { weight } \\
(\mathrm{Kg})\end{array}$ & $\begin{array}{c}\text { Additional } \\
\text { weight } \\
(\mathrm{Kg})\end{array}$ & $\begin{array}{c}\text { Total } \\
\text { weight } \\
(\mathrm{Kg})\end{array}$ & $\begin{array}{c}\text { Deflection } \\
\text { of the } \\
\text { spring } \\
(\mathrm{mm})\end{array}$ & $\begin{array}{c}\text { Number } \\
\text { of turns } \\
\text { locked } \\
\text { (Nos) }\end{array}$ \\
\hline 1 & 70 & 0 & 70 & 17 & 4 \\
\hline 2 & 70 & 50 & 120 & 22 & 7 \\
\hline 3 & 70 & 100 & 170 & 25 & 9 \\
\hline 4 & 70 & 150 & 220 & 27 & 11 \\
\hline
\end{tabular}

Table 3 Spring test for determining the Loading capacity with $\mathrm{V}-\mathrm{MEMBER}$ and suspension inclined at $45^{\circ}$ angle

\begin{tabular}{|c|c|c|c|c|c|}
\hline Sl.No & $\begin{array}{c}\text { Driver } \\
\text { weight } \\
(\mathrm{Kg})\end{array}$ & $\begin{array}{c}\text { Additional } \\
\text { weight } \\
(\mathrm{Kg})\end{array}$ & $\begin{array}{c}\text { Total } \\
\text { weight } \\
(\mathrm{Kg})\end{array}$ & $\begin{array}{c}\text { Deflection } \\
\text { of the } \\
\text { spring } \\
(\mathrm{mm})\end{array}$ & $\begin{array}{c}\text { Number } \\
\text { of turns } \\
\text { locked } \\
\text { (Nos) }\end{array}$ \\
\hline 1 & 70 & 0 & 70 & 14 & 2 \\
\hline 2 & 70 & 50 & 120 & 18 & 4 \\
\hline 3 & 70 & 100 & 170 & 20 & 6 \\
\hline 4 & 70 & 150 & 220 & 21 & 7 \\
\hline
\end{tabular}

Table 4 Spring test for determining the Loading capacity with $\mathrm{V}-\mathrm{MEMBER}$ and suspension inclined at $55^{\circ}$ angle

\begin{tabular}{|c|c|c|c|c|c|}
\hline Sl.No & $\begin{array}{c}\text { Driver } \\
\text { weight } \\
(\mathrm{Kg})\end{array}$ & $\begin{array}{c}\text { Additional } \\
\text { weight } \\
(\mathrm{Kg})\end{array}$ & $\begin{array}{c}\text { Total } \\
\text { weight } \\
(\mathrm{Kg})\end{array}$ & $\begin{array}{c}\text { Deflection } \\
\text { of the } \\
\text { spring }(\mathrm{mm})\end{array}$ & $\begin{array}{c}\text { Number of } \\
\text { turns } \\
\text { locked } \\
(\mathrm{Nos})\end{array}$ \\
\hline 1 & 70 & 0 & 70 & 15 & 2 \\
\hline 2 & 70 & 50 & 120 & 19 & 5 \\
\hline 3 & 70 & 100 & 170 & 21 & 6 \\
\hline 4 & 70 & 150 & 220 & 30 & 9 \\
\hline
\end{tabular}


Table 5 Spring test for determining the Loading capacity with $\mathrm{V}$-MEMBER and suspension inclined at $90^{\circ}$ angle

\begin{tabular}{|c|c|c|c|c|c|}
\hline Sl.No & $\begin{array}{c}\text { Driver } \\
\text { weight } \\
(\mathrm{Kg})\end{array}$ & $\begin{array}{c}\text { Additional } \\
\text { weight } \\
(\mathrm{Kg})\end{array}$ & $\begin{array}{c}\text { Total } \\
\text { weight } \\
(\mathrm{Kg})\end{array}$ & $\begin{array}{c}\text { Deflection } \\
\text { of the } \\
\text { spring } \\
(\mathrm{mm})\end{array}$ & $\begin{array}{c}\text { Number } \\
\text { of turns } \\
\text { locked } \\
\text { (Nos) }\end{array}$ \\
\hline 1 & 70 & 0 & 70 & 11 & 2 \\
\hline 2 & 70 & 50 & 120 & 18 & 5 \\
\hline 3 & 70 & 100 & 170 & 28 & 6 \\
\hline 4 & 70 & 150 & 220 & 39 & 8 \\
\hline
\end{tabular}

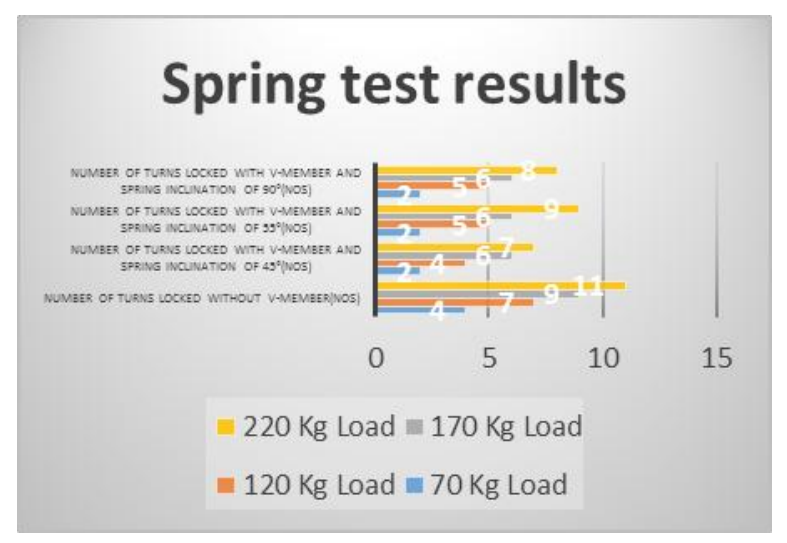

Fig. 3. Spring test for determining the Loading capacity of rear suspension with and without V-Member for various inclinations

From the above load test results, it is clear that the rear suspension equipped with V-Member has better load carrying capacities with the suspension inclination of $45^{\circ}$. The results clears indicates that the addition of the $\mathrm{V}$-Member enhances the load carrying capacity of the rear suspension and the locking of the helical springs are avoided. Since the locking of more number of spring turns are there, the comfortability in riding the vehicle will also be increased.

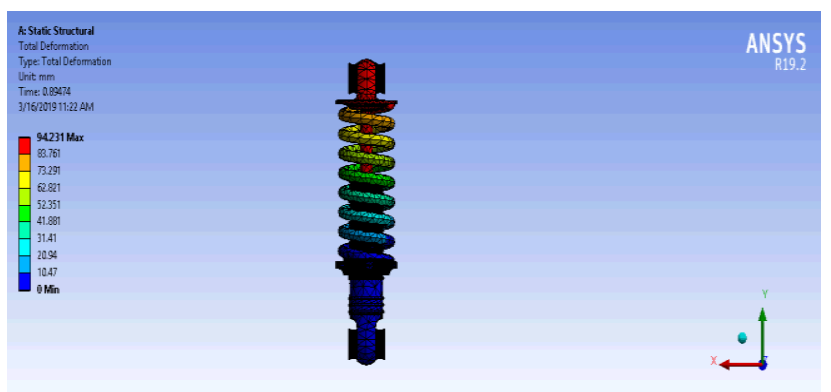

Fig. 4. Load test in ANSYS without V-Member

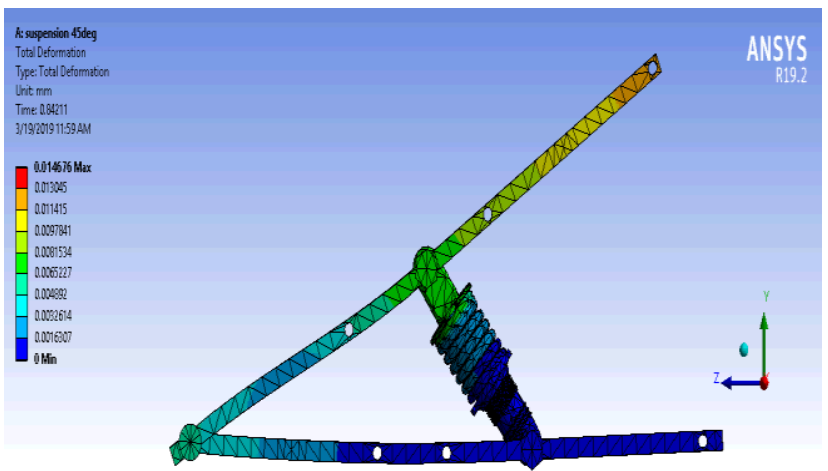

Fig. 5. Load test in ANSYS with V-Member and suspension inclination at $45^{\circ}$

In Fig 4, the suspension alone is subjected to the load and through ANSYS software, the deformation is observed as 0$36.747 \mathrm{~mm}$ at $150 \mathrm{~kg}$. In Fig 5 the suspension is equipped with the V-Member and the suspension is fitted at an inclination of $45^{\circ}$. The ANSYS software report clearly explain that the load is equally distributed along the $\mathrm{V}$-Member .The deformation is about $0-0.0146 \mathrm{~mm}$ at $170 \mathrm{~kg}$. In Fig 6, the suspension is equipped with the $\mathrm{V}$-Member fitted at $55^{\circ}$ inclination and the ANSYS software result indicates, the total deformation in the suspension unit it varies from $0-1.2875 \mathrm{~mm}$ at $170 \mathrm{~kg}$. In Fig 7, the suspension is equipped with the $\mathrm{V}$-member fitted at $90^{\circ}$ inclination and the ANSYS software result indicates, the load gets distributed through the $\mathrm{V}$-member and the deformation are lies between $0-0.0081196$ at $170 \mathrm{~kg}$. The rear suspension fitted with $\mathrm{V}$-Member at $45^{\circ}$ inclination of the suspension exhibits low stress and strain values at the ANSYS analysis, which is also a good indication for better load carrying and distribution ability of the member. There is only a slight variation between the load test carried out at real time and the load test carried out in software, which is within the acceptable range.

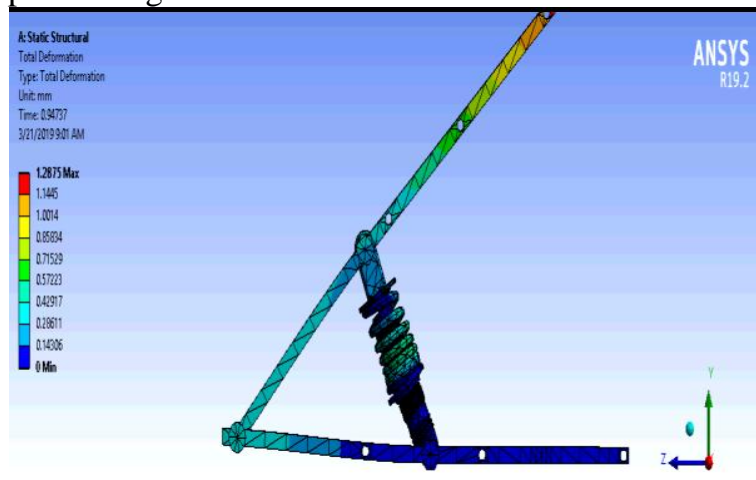

Fig. 6. Load test in ANSYS with V-Member and suspension inclination at $55^{\circ}$ 


\section{International Journal of Engineering Applied Sciences and Technology, 2019 \\ Vol. 4, Issue 2, ISSN No. 2455-2143, Pages 98-101 \\ Published Online June 2019 in IJEAST (http://www.ijeast.com)}

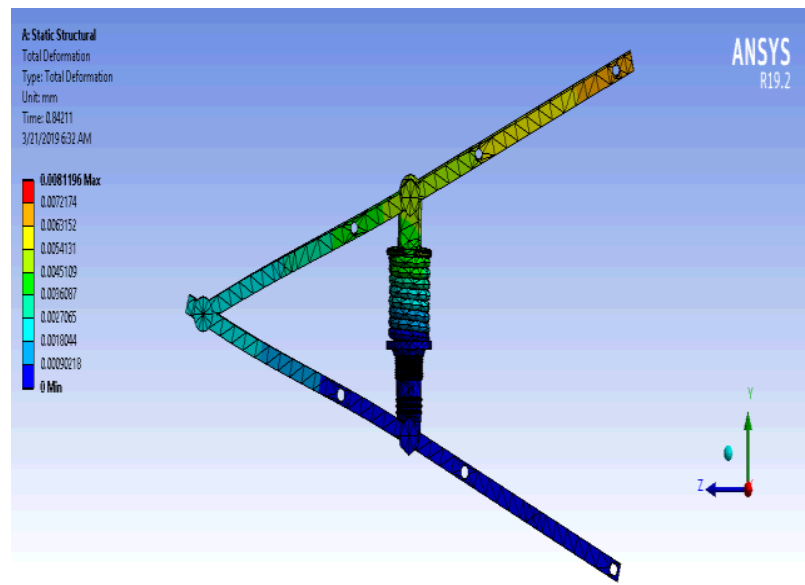

Fig. 7. Load test in ANSYS with V-Member and suspension inclination at $90^{\circ}$

\section{ACKNOWLEDGEMENT}

We would like to thank Mr. K. Chellamuthu, Assistant Professor, Department of Mechanical engineering, K.Ramakrishnan college of engineering, Trichy, for his valuable contribution for this work.

\section{CONCLUSION}

Through load test examining and analyzing the rear shock absorbers in ANSYS software with and without v member at various inclinations. It is observed that the load carrying capacity of the rear suspension can be enhanced by mounting the V-member, as the load was evenly shared and distributed through the V-Member.Hence better cushioning effect was given to the heavy duty vehicle at uneven roads and the load carrying capacity of the vehicle fitted with four shock absorbers and the vehicle fitted with two shock absorbers and two suspension was the same. By this we can also reduce the cost of the vehicle. Finally by observing the suspension fitted with V-Member at $45^{\circ}, 55^{\circ}, 90^{\circ}$ angles and found that, better suspension effect is achieved at $45^{\circ}$ inclination through real time load test and at ANSYS results.

\section{REFERENCES}

1. Pinjarla.Poormohan and Lakshmana Kishore $\mathrm{T}$ (2012), "Design and Analysis of a Shock Absorber", International Journal of Research in Engineering and Technology, ISSN: 2319-1163, Volume: 1, Issue: 4, pp.578592.

2. Kommalapati. Rameshbabu, Tippa Bhimasankar Rao (2013) , "Design Evaluation of a two wheeler suspension system for variable load conditions" International Journal of Computational Engineering Research, Vol 03, Issue 4, pp. 279-283.

3. Gajendra Singh Rathore and Upendra Kumar Joshi (2013), "Fatigue Stress analysis of helical Compression
Spring: A Review", International Journal of Emerging Trends in Engineering and Development, ISSN: 2249-6149, Volume: 2, Issue: 3, pp. 512-520,

4. B. Pyttel, I. Brunner, B. Kaiser, C. Berger, M. Mahendran (2013), "Fatigue behaviour of helical compression springs at a very high number of cyclesInvestigation of various influences", International Journal of Fatigue, S0142- 1123(13)00017-0, JIJF 3037

5. Mehdi Bakhshesh and Majid Bakhshesh (2012), "Optimization of Steel Helical Spring by Composite Spring", International journal of multidisciplinary science and engineering, vol.3, No.6,

6. B. Kaiser , B. Pyttel, C. Berger (2011), "VHCFbehavior of helical compression springs made of different materials", International journal of fatigue, vol 33,pp. 23-32.

7. S.M. Laws (2010), An Active Camber Concept for Extreme Manoeuvrability: Mechatronic Suspension Design, Tire Modelling, and Prototype Development (Doctoral dissertation), Stanford University.

8. M.S. Kumar (2008), Development of active suspension system for automobiles using PID controller, Proceedings of the World Congress on Engineering, 2.

9. Choudhery, K (2005), Variable camber suspension system, U.S. Patent 6874793, April 5. 